\title{
PRODUCTION OF UGBA CUBES FROM FERMENTED Pentaclethramacrophylla SEEDS
}

\section{OKORO C. U AND EMEFIEH C. V}

(Received 9 July 2018; Revision Accepted 14 August 2018)

\begin{abstract}
This research was designed as an innovation in the use of ugba as a food condiment. Production of "ugba" cubes from fermented seeds of Pentaclethramacrophylla ("ugba") was successfully carried out. Ugba seeds were dehulled after soaking overnight in warm water and shredded. Fermentation of the shredded "ugba" seeds was done using Bacillus subtilis pure culturedisolated from already fermented "ugba". Initial microbial study of the unfermented "ugba" showed the presence of Bacillus, Enterobacter, Penicillium, Aspergillus and yeast species. The initial bacterial count of the unfermented seed was $1.4 \times 10^{5} \mathrm{cfu} / \mathrm{g}$. Microbial counts of the "ugba" seeds after three days fermentation showed a disappearance of other microbial species except Bacillus species which was up to $9.60 \times 10^{4} \mathrm{cfu} / \mathrm{g}$. The shredded and fermented ugbaseeds were later milled and formed into cubes in a mould and oven dried.Sodium benzoate was used as a preservative. There was a drastic reduction of microbial count from $9.60 \times 10^{4} \mathrm{cfu} / \mathrm{g}$ to $4.80 \mathrm{x}$ $10^{4} \mathrm{cfu} / \mathrm{g}$ in "ugba" cubes preserved with sodium benzoate. Proximate composition of the "ugba" cubes showed increased levels of carbohydrates, ash and fibre content and a reduction in moisture protein and fats. Toxicological analysis of Bacillus fermented ugba presented low levels of hydrocyanic acid and soluble oxalates when compared with the unfermented sample. An overall acceptability of the ugba cubes was rated very highly when sensory evaluation was tested. This study recommends the use of Bacillus subtilis fermented nutritionally rich ugba cubes as a new innovation that will promote its acceptability worldwide.
\end{abstract}

KEYWORDS: Ugba, fermentation, Bacillus subtilis, sodium benzoate

\section{INTRODUCTION}

African oil bean, botanically known as Pentaclethra macrophylla Bentham is a tropical tree crop found mostly in the southern and middle belt regions of Nigeria and in other coastal parts of West and Central Africa (Key, 1989). It belongs to the family Leguminosae and its tree was recognized by Okafor (1982) as a food tree. The seeds comprise a grey coloured cotyledon, embedded in a glossy brownish, seed coat. Seeds are contained in a brownish, flattened pod which explodes at maturity and disperses the seeds (Enujiugha, 2003). A pod contains an average of 6-10 seeds; depending on the length of the pod. The fermented seeds of Pentaclethramarcrophylla are called "ugba" or "ukpaka" in Igbo language of Eastern Nigeria. It is widely consumed in this region as reported by Odunfa andOyeyiola (1985). It is known as "ukana" by the Efik and Ibibio people of Southern Nigeria and "ukpaka" in Benue state of North Central Nigeria. According to Tico (2005), ugba is a low acid food which could be prepared into flour and cubes and explored in food fortification and confectionaries.

The unfermented seeds are known to harbor a variety of microbial species such as Aspergillus, Staphylococcus, Micrococcus, PenicilliumandBacillus. However, it is belived that only bacteria species are involved in the fermentation of the seeds (Obeta, 1983).
Other species disappear in the course of fermentation. This was confirmed byOlasupoet al., (2016), who noted that no fungi or yeast has been implicated in the fermentation of ugba. Oil bean seeds require careful processing and fermentation before they can be eaten. Odunfa and Oyeyiola (1985) and Enujiugha (2000) showed that seeds must be boiled in water before removal of the seedcoat. Sokari and Wachukwu (1997) removed seed coats byroasting seeds on hot sand at 100degrees centigrade for 30 minutes. Ugba is known to be rich in proteins, carbohydrates and lipids. Minerals and vitamins are reported to be in small quantity in unfermented ugba. Kabuo et al., (2007) reported that ugba contains some flavourand aroma components like ethyl oleate and ethylphenol. This makes ugba a good flavouring and seasoning agent in soups and local dishes. The high moisture content of ugba as reported by Odunfa and Oyeyiola (1985) predisposes it to rapid spoilage. This is a great concern to many researchers although not much information is available on how to effectively preserve the delicacy. Therefore, this research is an innovation aimed at devising means of producing nutritionally and microbiologically safeugba cubes with a longer shelflife. The success of this

Okoro, C. U., Microbiology Department, University of Calabar, P.M.B.1115 Calabar - Nigeria.

Emefieh, C. V., Microbiology Department, University of Calabar, P.M.B.1115 Calabar - Nigeria. 
research will bring about increased availability of the product - ugba cubes, with its rich nutritional and organoleptic properties.

\section{MATERIALS AND METHODS}

Materials: - The materials used in this research include among others: oven, anaerobic jar, pressure pot, electric blender, kitchen knife, culture media, reagents and apparatus for biochemical and toxicological analysis of samples.

Sample Collection: - Dry seeds of Pentaclethramarcrophylla (ugba) were purchased from Nkwolagwa market in Umunukwu, Orwuato village of Mbaise Local Government Area of Imo State, Nigeria.

Sample Preparation: - The seeds were soaked in warm water overnight and dehulled.Cotyledons were sliced and boiled for one hour and washed in water. Portions were later homogenized in an electric blender and subjected to microbiological, toxicological and proximate analysis. Sliced cotyledonwere further subjected to fermentation.

\section{Microbiological analysis of unfermented ugba.}

A one-gram sample of ground ugba seed was analyzed for bacterial and fungi colonies using appropriate growth media (Nutrient agar-and Saboroud Dextrose Agar). This was done by spread plating the fourth step of a 10-fold serially diluted sample. Plates were incubated at 37degrees centigrade for Nutrient Agar plates and 72hours for SaboroudDextrose Agar plates on the shelf at room temperature.

\section{Identification and Characterization of Microbial Isolates}

Fungal isolates were subjected to fungal staining. All bacterial isolates were subjected to gram staining, spore staining, indole test, oxidationfermentation test, growth in $6.5 \%$ sodium chloride, motility test, catalase test, oxidase test and other useful identification and biochemical characterization tests were carried out.

\section{Fermentation of "ugba" and production of "ugba" cubes.}

The slicedugbaseeds were properly mixed with salt $(\mathrm{NaCl})$, inoculated with pure cultures ofBacillus subtilisand wrapped in sterile foil to ferment. Fermentation was for 3 days maintaining a microaerophilic environment.The fermented, slicedugba cotyledon were milled and mixed with a gelling agent (maize flour) and divided into two portions (samples 1 and 2). Sample 1 was further treated with $0.5 \%$ sodium benzoate but sample 2 had no preservative. Both samples were poured into moulds to form cubes. The ugba cubes were wrapped in foils and stored on the shelf for 4 weeks before further microbiological examination.

\section{Microbial, Proximate and Toxicological composition of ugba cubes}

After four (4) weeks of shelf storage, the ugba cubes (samples 1 and 2) were analyzed for microbial (bacterial and fungal) growth and proximate composition. For the proximate composition, parameters like moisture, crude fibre, ash, crude protein, fat and carbohydrate contents were analyzed using gravimetric method (AOAC, 1990),Weadne method (James, 1995), Kjeldal method. (Chang, 2003) and gravimetric method (Kiric and Sawyer, 1998) respectively. Methods described by Wood (2007) were used for analyzing toxicants in both fermented and unfermented ugba.

\section{Sensory Evaluation}

The method of Carmen (2013) was used to evaluate the acceptability and sensory quality of fermented ugba cubes and fermented dried ugba slices. A 6-membertrained panelist was used in evaluating the sensory attributes of the product. The panelists are people who taste the food and judge it and could be made up of one person or several hundreds depending on the type of sensory method as reported by Balàzs (2012). The panelists chosen for this evaluation were a group of six adults who have been eating shredded ugba for a period of 15 years. They are familiar with the taste, aroma, colour, and texture of ugba. The evaluation was carried out independently and without bias. The organoleptic qualities of colour, taste, texture, aroma and overall acceptability was carried out using a 9-point hedonic scale. One (1) for extremely disliked and nine (9) for liked extremely. Samples were used in the preparations of a local salad called "abacha" and coded for the panelists to rate. Table 4 reflects the sensory evaluation of ugba samples.

\section{Statistical Analysis}

Mean scores of results from the hedonic rating were subjected to analysis of variance (ANOVA). The significance of the mean differences of the samples was determined by Fischer's Least Significant Difference (LSD) as outlined by Ihekenonye and Ngoddy (1985). The LSD was defined at $\mathrm{P}<0.05$

\section{RESULTS AND DISCUSSIONS}

Microbiological Analysis.

Table 1 shows the microbial counts of unfermented ugba, fermented ugba cubes with $0.5 \%$ sodium benzoate and fermentedugba without preservatives. 
Table 1 Total Microbial Counts in Ugba samples.

\begin{tabular}{|c|c|c|c|c|}
\hline Samples & $\begin{array}{l}\text { Total microbial counts } \\
\text { (cfu/g) }\end{array}$ & $\begin{array}{l}\text { Bacterial } \\
\text { (cfu/g) }\end{array}$ & counts & $\begin{array}{l}\text { Fungal counts } \\
\text { (cfu/g) }\end{array}$ \\
\hline Unfermented ugba & $4.2 \times 10^{5}$ & $1.45 \times 10^{5}$ & & $1.02 \times 10^{5}$ \\
\hline $\begin{array}{l}\text { Fermented ugba cubes } \\
\text { (with preservative) }\end{array}$ & $4.80 \times 10^{4}$ & $4.80 \times 10^{4}$ & & Nil \\
\hline $\begin{array}{l}\text { Fermented ugba cubes } \\
\text { (without preservative) }\end{array}$ & $9.60 \times 10^{4}$ & $9.60 \times 10^{4}$ & & Nil \\
\hline
\end{tabular}

Table 2 Microbial Counts after 4 weeks storage

\begin{tabular}{|c|c|c|c|c|c|}
\hline Samples & \multicolumn{2}{|c|}{$\begin{array}{l}\text { Shelf storage (27-30degrees centigrade) } \\
\text { TMC (cfu/g) BC(sfu/g) FC(cfu/g) }\end{array}$} & \multicolumn{3}{|c|}{ Storage at 4degrees centigrade } \\
\hline $\begin{array}{l}\text { Fermented ugba } \\
\text { cubes (with } \\
\text { preservatives) }\end{array}$ & $2.4 \times 10^{4} \quad 1.7 \times 10^{4}$ & $1.2 \times 10^{4}$ & $2.3 \times 10^{4}$ & $2.1 \times 10^{4}$ & Nil \\
\hline $\begin{array}{l}\text { Fermented ugba } \\
\text { cubes (without } \\
\text { preservatives }\end{array}$ & $6.3 \times 10^{4}$ & $8.2 \times 10^{4}$ & $4.4 \times 10^{4}$ & $3.8 \times 10^{4}$ & $1.4 \times 10^{4}$ \\
\hline
\end{tabular}

Key:

TMC $=$ Total Microbial counts, $\mathrm{BC}=$ Bacterial Counts, $\mathrm{FC}=$ Fungal Counts

Table 2 shows the outcome of the microbiological analysis of ugba cubes stored on the shelf and in the refrigerator. The sample which had no chemical preservative had a total microbial count of $6.3 \times 10^{4} \mathrm{cfu} / \mathrm{g}$ on the shelf. The sample which contained $0.5 \%$ sodium benzoate had a total microbial count of $2.4 \times 10^{4} \mathrm{cfu} / \mathrm{g}$.

Table 3 Proximate composition of fermented and unfermented ugba

\begin{tabular}{llll}
\hline Parameters & $\begin{array}{l}\text { Fermented ugba(percent } \\
\text { weight) }\end{array}$ & $\begin{array}{l}\text { Unfermented ugba (percent } \\
\text { weight) }\end{array}$ \\
\hline Crude protein & 10.4 & 21.24 & \\
Carbohydrate & 24.51 & 18.10 & \\
Crude Fat & 26.06 & 52.67 & \\
Crude Fibre & 18.67 & 3.12 & \\
Ash Content & 16.00 & 2.51 & \\
Moisture Content & 4.37 & 2.36 \\
\hline
\end{tabular}

Table 4: Sensory Evaluation of ugba samples

\begin{tabular}{llllll}
\hline Ugba Samples & Aroma & Taste & Colour & Texture & $\begin{array}{l}\text { Overall } \\
\text { Acceptability }\end{array}$ \\
Unfermented Slices & 4 & 4 & 5 & 4 & 4 \\
Fermented Slices & 5 & 6 & 6 & 4 & 7 \\
Fermented Cubes & 7 & 8 & 7 & 6 & 8 \\
\hline
\end{tabular}

Key: 1 - dislike extremely, 2 - dislike very much, 3 - dislike moderately, 4 - dislike slightly, 5 - neither like nor dislike, 6 -like slightly, 7 - like moderately, 8 - liked extremely. 
Table 5: Toxicants in unfermented and fermented ugba ( $\mathrm{Mg} / 100 \mathrm{~g}$ dry matter)

\begin{tabular}{llllll}
\hline Sample & $\begin{array}{l}\text { Hydrocyanic } \\
\text { acid }\end{array}$ & $\begin{array}{l}\text { Soluble } \\
\text { oxalates }\end{array}$ & $\begin{array}{l}\text { Total } \\
\text { oxalates }\end{array}$ & Tannins & Phytates \\
Control & $1.03 \pm 0.01$ & $11.77 \pm 0.01$ & $20.13 \pm 0.01$ & $0.04 \pm 0.01$ & $0.04 \pm 0.01$ \\
$\begin{array}{l}\text { Fermented in leaf } \\
\text { Fermented in B. subtilis }\end{array}$ & $1.23 \pm 0.01$ & $6.92 \pm 0.01$ & $16.18 \pm 0.02$ & $4.44 \pm 0.01$ & $0.35 \pm 0.01$ \\
broth culture & $1.31 \pm 0.01$ & $8.91 \pm 0.01$ & $20.24 \pm 0.01$ & $0.91 \pm 0.01$ & $0.51 \pm 0.01$ \\
\hline
\end{tabular}

The toxicological analysis shown on Table 5 reveals that there was a slight increase in total oxalate from $20.13 \pm 0.01$ to $20.24 \pm 0.01$. The phylate content also increased from $0.49 \pm 0.01$ to $0.51 \pm 0.01$. However, fermentation of ugba with Bacillus subtilis broth culture reduced the tannin content from $0.04 \pm 0.01$ to $0.19 \pm 0.01$. soluble oxalate in the same sample was reduced from $11.77 \pm 0.01$ to $8.91 \pm 0.01$. All results were measured as milligrams per $100 \mathrm{~g}$ dry matter $(\mathrm{Mg} / 100 \mathrm{~g}$ dry matter)

\section{DISCUSSION, CONCLUSION RECOMMENDATIONS}

AND

The production of "ugba" cubes is an innovation aimed at adding value to the existing conventional method of slice, ferment and consume. This old method of eating the ugba immediately after fermentation, makes the product unacceptable to people of other cultures. When ugba is preserved in cubes as bouillion, people from other cultures will be able to assess it and derive its high nutritional potentials. This way the product will be available at off-seasons.

In this study, fermentation of the cotyledon led to the softening of the cotyledon and a drastic disappearance of other microbial species except Bacillus species which was up to $9.60 \times 10^{4} \mathrm{cfu} / \mathrm{g}$. Addition of preservatives brought about drastic reduction of microbes during storage at different storage conditions. According to Fawole and Osho (2002), the use of preservatives on food may be microbiocidal and kill the target organism or they may be microbiostatic and simply prevent them from growing, thus improving the shelf life of the product. This could be the reason behind the drastic reduction in the total bacterial count of ugba cubes treated with $0.5 \%$ sodium benzoate.

The results of the proximate analysis showed an increase for carbohydrates, ash and fibre, but a decrease in protein and fat content. This decrease could be due to heat treatmentwhich led to protein denaturation and melting of fats. The proximate composition of the unfermented ugba is similar to the results of Enujiugha and Akanbi (2002) where the results for crude protein, carbohydrate, lipid, crude fibre and ash contents were $22.32 \% \quad 19.16 \%, \quad 53.98 \%, \quad 2.13 \%$ and $2.40 \%$ respectively. There was also a decrease in moisture content from $4.37 \%$ after fermentation to $2.36 \%$ moisture after oven during. At this temperature microbes rarely survive. Toxicological composition of fermented and unfermented ugba shows a decrease in soluble oxalades. The tannins and phytate contents of fermented ugba samples, increases significantly. This could be due to browning reaction caused by some enzymatic activities in the product.
In conclusion, the results and discussion of this research suggests that seeds of the African Oil bean (Pentaclethra macrophylla) tree could be fermented, milledand formed into seasoning cubes. This will increase the availability and acceptability of ugba for use in confectionaries and fortification of foods. It could also be suggested that chemical preservatives together with drying could be used to improve the keeping quality of ugba cubes. However, drying at a lower temperature (about $50^{\circ} \mathrm{C}$ ) may yield a more nutritious product, with less damage on the protein content.As reported by Ohiri and Bassey (2017), fermentation of ugba improved its flavor and reduced the lipid content to a healthy level. The aroma of fermented ugba, as deduced by Nwokolo, and Ugwuanyi (2015) is due to the presence of methyl esters of various long chain fatty acids. This claim was upheld with sensory evaluation. It is therefore recommended that fermentation of ugba using Bacillus subtillisbroth culture should be adopted as it helps in the improvement of the nutritional microbiological and toxicological quality of the product.

\section{REFERENCES}

A.O.A. C., 1990. Methods of Analysis. Association of Official Analytical Chemists, $15^{\text {th }}$ Edition, Washington, D.C.

Chang 2003. Protein Analysis in: Food Analysis, $3^{\text {rd }}$ Edition, Plenum Publishers, New York.

Enujiugla, V.N., 2000. Development of a new food paste from seeds of Pentaclethra species. App. Trop.AgricApril, 5:89-94.

Enujuigha, V.N., 2003. Nutrient changes during the fermentation of Africa Oil bean (Pentachlethra macrophylla Benth) seeds. Pak. J. Nutr., 2:320323.

Fawole, M.O. and Osho, B.A., 2002. Laboratory Manual of Microbiology. Spectrum Books Ltd, Ibadan: 645.

Ihekoronye, A. I and Ngoddy, P. O, 1985. Integrated Food Science and Technology for the Tropics. Macmillan Publishers, London. Pp. 17-19, 165269.

James, C.S., 1995. Analytical Chemistry of foods. Blackie Academic and Professional Publishers, New York. 
Kabuo, N.O., Uzuegbu, J.O., Ubbaonu, C.N. and Onyeka, E.U., 2007. Effect of chemical compounds produced by microorganisms on organoleptic properties of Ugba (PentachlethramacrophyllusBenth) during fermentation. Proceedings of the Annual conference of Nigeria Institute offood Science and Tachnology, Oct, 22-25, Abuja, Nigeria : 175-176.

Keay, R.S. and Sawyer, R., 1995. Pearson's Composition and Analysis of Foods. Publ. Church Hill Livingstone, Edinburagh.

Nurudeen A. Olapuso, Chimezie P. Okorie and Folarin A. Oguntoyinbo 2016. The Biotechnology of ugba, a Nigerian Food Condiment.

Nwokeleme, C. O and Ugwuanyi, J. O., 2015. Evolution of flavor compounds during fermentation of African oil bean seeds for ugba production. International Journal of Food Science 706328. Doi: 10.1155

Obeta, J.A.N., 1983. A note on the micro-organisms associated with the fermentation of seeds of the African Oil bean tree (Pentachlethra macrophylla). J. Applied Bacteriology, 54:433.

Odunga, S.A. and Oyeyiola, G.F., 1985. Microbiological study of the fermentation of Ugba - A Nigerian indigenous fermented food flavour.

J. Plant foods, $6: 155-163$.

Ohiri, R. C and Bassey E. E., 2017. Fermentation induced changes in volatile components of African oil bean (Pentaclethra macrophylla Beenth) Food Science Nutrition 5(4):948-955. Doi: $10.1002 / f s n 3.481$

Okafor, J.C., 1982 Promising Trees of Agro forest in Southern Nigeria, IN: Agro forestry in the African Humid Tropics.

Ed. L.H. MacDonald (Proceeding of a workshop held in Ibadan, Nigeria, $27^{\text {th }}$ April $-1^{\text {st }}$ May, 1981). Published by the United Nations University Press, Tokyo, Japan.

Sokari, T.G. and Wachukwu, C.K., 1997. Single rapid processing of African oil beans for ugbaproduction. International Journal of food Sciences and Technology, 32:77-79.

Tico Etnobotanical Dictionary 2005. Pentachlethra macrophylla Benth. http:www_arsgrin.gov/duke/dictionary/tico/p.html.

Wood, Roger (2007). Food Toxicants Analysis. Food Standards Agency, Norwich Research Park, United Kingdom 